\title{
Response of Stargrass to Fertilizer and Solid Cattle Manure in Puerto Rico'
}

\author{
Jaime Vélez-Santiago, José A. Arroyo-Aguilú, and \\ José E. Rodriguez-Arroyo ${ }^{2}$
}

\begin{abstract}
A field experiment conducted in 1981 and 1982 at the Corozal Substation to determine the effects of solid cattle manure on the green forage, dry forage, and crude protein yields of stargrass (Cynodon nlemfuensis var. nlemfuensis) and on soil composition, showed that after 720 days the maximum manure application, without supplemental nitrogen fertilization, increased dry forage and crude protein yields significantly over the unfertilized control. Solid manure $65 \%$ dry matter and $1.6 \%$ nitrogen, $.10 \%$ phosphorus, and $.34 \%$ potassium; was applied at six rates $(2,800,5,600,11,200,16,800,22,400$ and $31,360 \mathrm{~kg} /$ ha/year) Stargrass harvested every 45 days. Manure treatments were supplemented with commercial fertilizer to provide 504, 73, and $336 \mathrm{~kg} / \mathrm{ha} /$ year of $\mathrm{N}, \mathrm{P}$ and $\mathrm{K}$, respectively. Two check treatments were included: one received $3,360 \mathrm{~kg} / \mathrm{ha} /$ year of 15-5-10 fertilizer as a standard fertilization and the other received neither fertilizer nor manure. Surface-applied manure at rates of $2,800,5,600,11,200,16,800$ and $22,400 \mathrm{~kg} / \mathrm{ha} /$ year, supplemented with $\mathrm{N}, \mathrm{P}$ and $\mathrm{K}$, and the fertilized control gave similar dry forage yields.

Stargrass $\mathrm{P}$ content tended to increase with manure applications, but $\mathrm{K}, \mathrm{Ca}$ and $\mathrm{Mg}$ contents were similar to the standard fertilization. Soil available $\mathbf{P}$ and exchangeable $\mathrm{K}$ tended to increase with manure applications.
\end{abstract}

\section{INTRODUCTION}

According to Semple (5), a 591-kg cow produces $19047 \mathrm{~kg}$ of manure annually, $77 \%$ dung and $23 \%$ urine. One thousand $\mathrm{kg}$ of manure contain about $5.5 \mathrm{~kg}$ of elemental (N), $1.5 \mathrm{~kg} \mathrm{P}_{2} \mathrm{O}_{5}, 4 \mathrm{~kg}$ of $\mathrm{K}_{2} \mathrm{O}$, and $250 \mathrm{~kg}$ of dry organic matter. The organic matter of the manure is extremely valuable, since it improves tilth, makes it more absorptive to rainfall, improves drainage, and reduces erosion. Because of the increasing use and size of confinement systems in livestock operations, where land holdings are small, such as in Puerto Rico, manure is often available in large quantities.

The beneficial effects of cattle manure have long been known. Arteaga et al. (1) reported that $30,000 \mathrm{~kg} / \mathrm{ha}$ of cattle manure at planting time sustained $\mathrm{P}$ concentrations in grasses and soils and produced dry forage (DF) yields equal to other commercial $\mathrm{P}$ sources or better. Jones and Robinson (2) reported that cattle manure at 49,400 kg/ha annually raised yields of Napiergrass (Pennisetum purpureum) consistently, and responses were more evident in a steep and eroded red loam soil. Sears et al. (4) reported that DF yields were more than trebled by returning cattle

${ }^{1}$ Manuscript submitted to Editorial Board August 20, 1984.

${ }^{2}$ Associate Agronomist, Corozal Substation; Nutritionist, Animal Industry Department; and Research Technician, Corozal Substation, respectively, Agricultural Experiment Station, Mayagüez Campus, University of Puerto Rico, Río Piedras, P. R. 
manure to pasture as compared to the control. Sutton et al. (7) reported that solid cattle manure applied at $49,000 \mathrm{~kg} / \mathrm{ha}$ increased significantly corn yields over the control.

In spite of the great amounts of cattle manure available in the dairies of Puerto Rico, no local research has been conducted to study its potential as a fertilizer source. The objectives of this research were to determine the effects of different rates of solid cattle manure on the yield and chemical composition on Stargrass (Cynodon nlemfuensis var. nlemfuensis PRPI 2341) ${ }^{3}$ and on soil composition in the humid mountain region of Puerto Rico.

\section{MATERIALS AND METHODS}

The experiment was conducted at the Corozal Substation in the humid mountain region of Puerto Rico. The soil is a Corozal clay (Ultisol) of

TABLE 1.-Fertilization treatments

\begin{tabular}{|c|c|c|c|c|c|c|c|}
\hline \multirow{2}{*}{ Treatment } & \multirow{2}{*}{$\begin{array}{l}\text { Solid } \\
\text { cattle } \\
\text { manure }\end{array}$} & \multicolumn{3}{|c|}{ Manure composition" } & \multicolumn{3}{|c|}{$\begin{array}{c}\text { Supplemental nutrients added to } \\
\text { manure }\end{array}$} \\
\hline & & Nitrogen & Phosphorus & Potassium & Nitrogen & Phosphorus & Potassium \\
\hline & $\mathrm{kg} / \mathrm{ha} / \mathrm{yr}$ & & $\mathrm{kg} / \mathrm{ha}$ & & & $\mathrm{kg} / \mathrm{ha}$ & \\
\hline $1^{2}$ & 0 & 0 & 0 & 0 & 504 & 73 & 336 \\
\hline 2 & 2,800 & 45 & 4 & 8 & 459 & 69 & 270 \\
\hline 3 & 5,600 & 90 & 6 & 17 & 414 & 67 & 261 \\
\hline 4 & 11,200 & 179 & 11 & 35 & 325 & 62 & 243 \\
\hline 5 & 16,800 & 269 & 17 & 53 & 235 & 56 & 225 \\
\hline 6 & 22,400 & 358 & 23 & 71 & 146 & 50 & 207 \\
\hline 7 & 31,360 & 504 & 35 & 104 & 0 & 38 & 174 \\
\hline $8^{3}$ & 0 & 0 & 0 & 0 & 0 & 0 & 0 \\
\hline
\end{tabular}

${ }^{1}$ Dry cow manure contained $1.6,0.10$, and $0.34 \%$ of $\mathrm{N}, \mathrm{P}$ and $\mathrm{K}$, respectively.

${ }^{2} 3360 \mathrm{~kg} / \mathrm{ha} /$ year of $15-5-10$ fertilizer.

${ }^{3}$ No fertilizer and no manure.

medium natural fertility, according to the soil survey of the San Juan area. ${ }^{4}$ Before beginning the study, the first $15 \mathrm{~cm}$ layer of soil had a $\mathrm{pH}$ of 5.0 , with exchangeable $\mathrm{K}$ and $\mathrm{P}$ contents of $163 \mathrm{p} / \mathrm{m}$ and $0 \mathrm{p} / \mathrm{m}$, respectively.

A 1-year Stargrass stand was divided into 32 plots of $1.83 \times 4.88 \mathrm{~m}$ each, in order to include 8 fertilization treatments (table 1). Each plot was surrounded by ditches. A complete block design with four replications was employed.

${ }^{3}$ Material was introduced through S-9 (H-94) Regional Project.

${ }^{4}$ Soil survey of the San Juan area of Puerto Rico, 1978. USDA. Soil Conservation Service in cooperation with the Agricultural Experiment Station, University of Puerto Rico. 
Two-year old, sun-cured, solid cattle manure ${ }^{5}$ from a private dairy farm in the lowlands of Manati was utilized. Mean composition of manure applied over 2 years (1981-82) at 6 rates was $65,1.6, .10$ and .34\% of dry matter (DM), N, P, and K, respectively. Manure treatments on a dry basis were: 2,800 (T2), 5,600 (T3), 11,200 (T4), 16,800 (T5), 22,400 (T6), and 31,360 (T7) kg/ha/yr. Manure treatments were supplemented with a 15-5-10 commercial fertilizer so as to provide 504, 73, and $336 \mathrm{~kg} / \mathrm{ha} /$ yr of $\mathrm{N}, \mathrm{P}$, and $\mathrm{K}$, respectively. Two additional treatments, $3,360 \mathrm{~kg} / \mathrm{ha} /$ yr of a 15-5-10 fertilizer (T1), and no fertilizer nor manure (T8), were also included. Manure was surface-applied in December 1980, July 1981, November 1981, and May 1982. Calcium carbonate was surface-applied at a rate of $2,240 \mathrm{~kg} / \mathrm{ha} / \mathrm{yr}$ in one application to maintain the $\mathrm{pH}$ at approximately 5.7 .

Stargrass plots were harvested at approximately 5 -cm height above ground every 45 days during 2 consecutive years from November 1980 through November 1982. The forage was weighed, sampled, dried at $55^{\circ}$ $\mathrm{C}$ in a forced air oven, ground in a Wiley mill ${ }^{6}$ to pass a $1-\mathrm{mm}$ screen, and stored in plastic bags. DM content was determined in all samples. Annual forage samples were composited by replicates of each treatment and analyzed for $\mathrm{N}, \mathrm{P}$, and $\mathrm{K}$. Total $\mathrm{N}$ content was determined with a Technicon Autoanalyzer and $\mathrm{P}$ and $\mathrm{K}$ contents by the method described by Riera (3). Crude protein (CP) was calculated as $\mathrm{N} \times 6.25$. Ca and $\mathrm{Mg}$ contents were analyzed by flame photometry after digestion with nitric and perchloric acids.

During the first year (December 5, 1980 to November 13, 1981), total rainfall was 2,438 $\mathrm{mm}$. Rainfall during the second year (Nov. 14, 1981 to Nov. 5, 1982) was $1,699 \mathrm{~mm}$. No irrigation was used. Ambient mean temperatures were $24.7^{\circ} \mathrm{C}$ in 1981 and $24.8^{\circ} \mathrm{C}$ in 1982.

The data for green forage (GF), DF, and CP yields and for DM content were subjected to variance analysis and to Duncan's multiple range test (6). They were grouped for analysis into first year (8 cuttings), second year ( 8 cuttings), and both years combined (16 cuttings).

\section{RESULTS AND DISCUSSION}

Table 2 shows yields during the first 360 days of the study. The standard fertilization treatment (T1) outyielded significantly the maximum manure (T7) and unfertilized control (T8) treatments in GF, DF,

\footnotetext{
${ }^{5}$ Hereafter, manure refers to dung plus some decomposed 2-year sun-cured straw, stored at ambient temperature.

${ }^{6}$ Trade names in this publication are used only to provide specific information. Mention of a trade name does not constitute a warranty of equipment or materials by the Agricultural Experiment Station of the University of Puerto Rico, nor is this mention a statement of preference over other equipment or materials.
} 


\section{JOURNAL OF AGRICULTURE OF UNIVERSITY OF PUERTO RICO}

and CP (table 2). The mean DM content of T8 (30.21\%) was significantly higher than that of the remaining treatments. Treatments involving manure applications up to $22,400 \mathrm{~kg} /$ ha/year plus supplemental N (T2 through T6) significantly increased DF yields over T7 and T8 and produced similar yields as T1 (table 2). However, CP yields were lower in all of the manure treatments except T2. Apparently the C:N ratio in the manure was too wide, and decomposing bacteria competed with the grass for N. Hence, a pale yellow color was observed in the plants subjected to T7. DF and CP yields were normal for treatments up to T6, when compared to those reported at the same site with a fertilization rate of $2,240 \mathrm{~kg} / \mathrm{ha} /$ year (8).

TABLE 2.-Green forage, dry forage, crude protein yields, and dry matter content of stargrass, with and without surface applied manure, harvested between December 5, 1980 and November 13,1981

\begin{tabular}{|c|c|c|c|c|c|}
\hline Treatment & $\begin{array}{c}\text { Solid } \\
\text { cattle } \\
\text { manure }\end{array}$ & $\begin{array}{l}\text { Green } \\
\text { forage } \\
\text { yield }\end{array}$ & $\begin{array}{c}\text { Dry } \\
\text { matter } \\
\text { content }\end{array}$ & $\begin{array}{l}\text { Dry } \\
\text { forage } \\
\text { yield }\end{array}$ & $\begin{array}{l}\text { Crude } \\
\text { protein } \\
\text { yield }\end{array}$ \\
\hline & $\mathrm{kg} / \mathrm{ha} / \mathrm{yr}$ & $\mathrm{kg} / \mathrm{ha}$ & $\%$ & $\mathrm{~kg} / \mathrm{ha}$ & $\mathrm{kg} / \mathrm{ha}$ \\
\hline $1^{1}$ & 0 & $105,337 a^{2}$ & $25.62 c$ & $26,782 \mathrm{a}$ & 3,925 a \\
\hline 2 & 2,800 & $92,098 \mathrm{ab}$ & $26.95 \mathrm{bc}$ & 24,469 a & $2,892 \mathrm{ab}$ \\
\hline 3 & 5,600 & 86,407 b & $26.42 \mathrm{bc}$ & 22,664 a & $2,564 \mathrm{~b}$ \\
\hline 4 & 11,200 & $96,761 \mathrm{ab}$ & $26.54 \mathrm{bc}$ & 25,687 a & $2,710 \mathrm{~b}$ \\
\hline 5 & 16,800 & $86,140 \mathrm{~b}$ & 27.22 bc & 23,472 a & $2,507 \mathrm{~b}$ \\
\hline 6 & 22,400 & $87,614 a b$ & $26.82 \mathrm{bc}$ & $23,500 \mathrm{a}$ & $2,442 \mathrm{~b}$ \\
\hline 7 & 31,360 & $66,638 \mathrm{c}$ & $27.88 \mathrm{bc}$ & $18,380 \mathrm{~b}$ & $1,791 \mathrm{c}$ \\
\hline $8^{3}$ & 0 & $45,992 \mathrm{~d}$ & $30.21 \mathrm{a}$ & $13,588 \mathrm{c}$ & $1,422 \mathrm{c}$ \\
\hline
\end{tabular}

$3,360 \mathrm{~kg} / \mathrm{ha} /$ year of $15-5-10$ fertilizer.

${ }^{2}$ Means in the same column followed by 1 or more letters in common do not differ significantly at the $5 \%$ probability level.

${ }^{3}$ No fertilizer and no manure.

Table 3 shows yields during the second 360 days of the study. During this period, DF yields in general decreased in relation to the previous cropping year, especially so for T8, where the decrease was $64 \%$. Yields of CP showed the same trend. The main reasons for this decline were low rainfall and deterioration of the control plots as a result of lack of fertilization. In spite of the relatively low yields, the data in table 3 show that applications up to $11,200 \mathrm{~kg} / \mathrm{ha}$ of manure (T2, T3, T4) produced as high DF yields as T1. However, T1 produced a significantly higher CP yield. Rainfall during the second 360-day period was $30 \%$ less than during the former period. Throughout the study, weeds such as Amaranthus spinosus and Portulaca oleracea germinated in plots of T2 through T7 but not in those of $\mathrm{T} 1$ and $\mathrm{T} 8$. Weeds were most prominent in T7. These 
TABLE 3.-Green forage, dry forage, crude protein yields, and dry matter content of stargrass with and without surface applied manure, harvested between November 14, 1981 and November 5, 1982

\begin{tabular}{cccccc}
\hline Treatment & $\begin{array}{c}\text { Solid } \\
\text { cattle } \\
\text { manure }\end{array}$ & $\begin{array}{c}\text { Green } \\
\text { forage } \\
\text { yield }\end{array}$ & $\begin{array}{c}\text { Dry } \\
\text { matter } \\
\text { content }\end{array}$ & $\begin{array}{c}\text { Dry } \\
\text { forage } \\
\text { yield }\end{array}$ & $\begin{array}{c}\text { Crude } \\
\text { protein } \\
\text { yield }\end{array}$ \\
\hline $\begin{array}{c}\mathrm{kg} / \mathrm{ha} / \mathrm{yr} \\
\mathrm{I}^{1}\end{array}$ & 0 & $68,747 \mathrm{a}^{2}$ & $26.50 \mathrm{~b}$ & $17,758 \mathrm{a}$ & $2,765 \mathrm{a}$ \\
2 & 2,800 & $65,215 \mathrm{ab}$ & $26.89 \mathrm{~b}$ & $16,641 \mathrm{ac}$ & $2,390 \mathrm{~b}$ \\
3 & 5,600 & $62,191 \mathrm{ab}$ & $26.75 \mathrm{~b}$ & $15,518 \mathrm{ac}$ & $2,096 \mathrm{~b}$ \\
4 & 11,200 & $66,917 \mathrm{ab}$ & $26.37 \mathrm{~b}$ & $16,908 \mathrm{ab}$ & $2,100 \mathrm{~b}$ \\
5 & 16,800 & $56,715 \mathrm{~b}$ & $26.97 \mathrm{~b}$ & $13,912 \mathrm{~cd}$ & $1,674 \mathrm{c}$ \\
6 & 22,400 & $57,071 \mathrm{~b}$ & $26.79 \mathrm{~b}$ & $14,529 \mathrm{bd}$ & $1,597 \mathrm{c}$ \\
7 & 31,360 & $45,890 \mathrm{c}$ & $26.94 \mathrm{~b}$ & $11,821 \mathrm{~d}$ & $1,221 \mathrm{~d}$ \\
$8^{3}$ & 0 & $17,926 \mathrm{~d}$ & $29.42 \mathrm{a}$ & $5,145 \mathrm{e}$ & $579 \mathrm{e}$ \\
\hline
\end{tabular}

${ }^{1} 3,360 \mathrm{~kg} / \mathrm{ha} /$ year of $15-5-10$ fertilizer.

${ }^{2}$ Means in the same column followed by 1 or more letters in common do not differ significantly at the $5 \%$ probability level.

${ }^{3}$ No fertilizer and no manure.

TABLE 4.-Total green forage, dry forage, crude protein yields, and dry matter content of stargrass, with and without surface applied manure, during 720 days

\begin{tabular}{crcccc}
\hline Treatment & $\begin{array}{c}\text { Solid } \\
\text { cattle } \\
\text { manure }\end{array}$ & $\begin{array}{c}\text { Green } \\
\text { forage } \\
\text { yield }\end{array}$ & $\begin{array}{c}\text { Dry } \\
\text { matter } \\
\text { content }\end{array}$ & $\begin{array}{c}\text { Dry } \\
\text { forage } \\
\text { yield }\end{array}$ & $\begin{array}{c}\text { Crude } \\
\text { protein } \\
\text { yield }\end{array}$ \\
\hline & $\mathrm{kg} / \mathrm{ha} / \mathrm{yr}$ & $\mathrm{kg} / \mathrm{ha}$ & $\%$ & $\mathrm{~kg} / \mathrm{ha}$ & $\mathrm{kg} / \mathrm{ha}$ \\
$1^{1}$ & 0 & $174,084 \mathrm{a}^{2}$ & $26.06 \mathrm{~b}$ & $44,615 \mathrm{a}$ & $6,070 \mathrm{a}$ \\
2 & 2,800 & $157,313 \mathrm{ab}$ & $26.92 \mathrm{~b}$ & $41,224 \mathrm{a}$ & $5,299 \mathrm{ab}$ \\
3 & 5,600 & $148,597 \mathrm{ab}$ & $26.58 \mathrm{~b}$ & $38,240 \mathrm{a}$ & $4,660 \mathrm{bc}$ \\
4 & 11,200 & $163,678 \mathrm{ab}$ & $26.46 \mathrm{~b}$ & $43,102 \mathrm{a}$ & $4,862 \mathrm{bc}$ \\
5 & 16,800 & $142,855 \mathrm{~b}$ & $27.09 \mathrm{~b}$ & $37,637 \mathrm{a}$ & $4,209 \mathrm{c}$ \\
6 & 22,400 & $144,685 \mathrm{~b}$ & $26.80 \mathrm{~b}$ & $38,593 \mathrm{a}$ & $4,098 \mathrm{c}$ \\
7 & 31,360 & $112,528 \mathrm{c}$ & $27.41 \mathrm{~b}$ & $30,678 \mathrm{~b}$ & $3,059 \mathrm{~d}$ \\
$8^{3}$ & 0 & $63,919 \mathrm{~d}$ & $29.82 \mathrm{a}$ & $18,733 \mathrm{c}$ & $2,021 \mathrm{e}$ \\
\hline
\end{tabular}

${ }^{1} 3,360 \mathrm{~kg} / \mathrm{ha} /$ year of $15-5-10$ fertilizer.

${ }^{2}$ Means in the same column followed by 1 or more letters in common do not differ significantly at the $5 \%$ probability level.

${ }^{3}$ No fertilization and no manure.

weeds are not common in Corozal but are considered principally weeds of the waterlogged lowlands where the manure was obtained.

Table 4 and figure 1 show the data accumulated during the 720-day period (16 cuttings). T7 increased DF and CP yields by 64 and $51 \%$ over T8, respectively. There were no statistically significant differences between standard fertilization (T1) and T2 through T6 (table 4) in terms of DF yields. Again, T1 yielded significantly more CP than T3 through T7. 


\section{JOURNAL OF AGRICULTURE OF UNIVERSITY OF PUERTO RICO}

Table 5 shows the mean percentage composition of stargrass of the 8 treatments harvested during the 720 -day period in terms of $\mathrm{CP}, \mathrm{Ca}, \mathrm{P}$, $\mathrm{K}$, and $\mathrm{Mg}$ contents. In general, the CP content of stargrass was higher for T1 than for T2 through T8. However, P content for T3 through T7

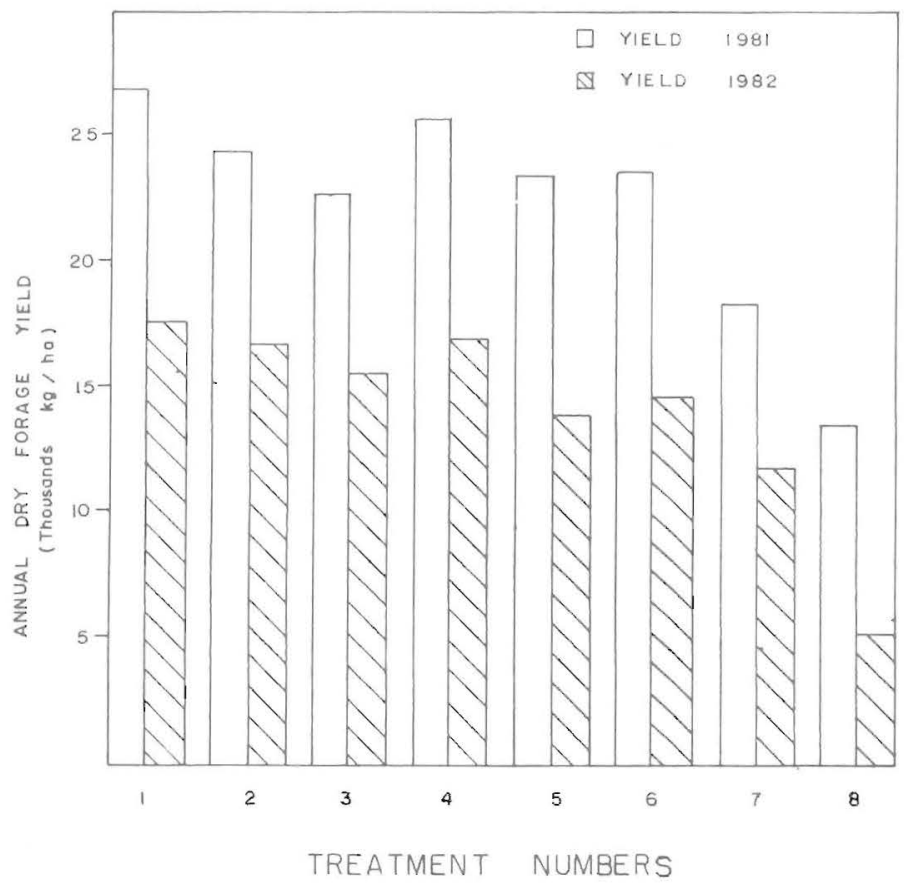

Fig. 1.-Annual dry forage yields as affected by solid cattle manure rates and fertilizer applications.

TABLE 5.-Mean crude protein and mineral contents of stargrass, with and without surface applied manure, harvested during 720 days

\begin{tabular}{|c|c|c|c|c|c|c|}
\hline Treatment & $\begin{array}{c}\text { Solid } \\
\text { cattle } \\
\text { manure }\end{array}$ & $\begin{array}{l}\text { Crude } \\
\text { protein }\end{array}$ & Phosphorus & Potassium & Calcium & Magnesium \\
\hline & $\mathrm{kg} / \mathrm{ha} / \mathrm{yr}$ & & & $\%$ & & \\
\hline $1^{1}$ & 0 & 14.0 & .23 & 2.30 & .51 & .30 \\
\hline 2 & 2,800 & 13.0 & .23 & 2.26 & .51 & .28 \\
\hline 3 & 5,600 & 12.5 & .25 & 2.42 & .52 & .30 \\
\hline 4 & 11,200 & 11.6 & .26 & 2.47 & .53 & .32 \\
\hline 5 & 16,800 & 11.4 & .26 & 2.45 & .53 & .29 \\
\hline 6 & 22,400 & 10.8 & .28 & 2.46 & .54 & .29 \\
\hline 7 & 31,360 & 10.0 & .30 & 2.32 & .55 & .29 \\
\hline $8^{2}$ & 0 & 11.0 & .19 & 1.82 & .51 & .29 \\
\hline$\overline{\mathbf{x}}$ & & 11.8 & .25 & 2.31 & .53 & .30 \\
\hline
\end{tabular}

${ }^{1} 3,360 \mathrm{~kg} / \mathrm{ha} / \mathrm{yr}$ of $15-5-10$ fertilizer.

${ }^{2}$ No fertilizer and no manure. 
was higher to that for T1 and T2. This finding agrees with those of Arteaga et al. (1) in that high amounts of cattle manure $(30,000 \mathrm{~kg} / \mathrm{ha})$ maintain $\mathrm{P}$ concentrations in the forage equal or higher to those resulting from the use of other commercial $\mathrm{P}$ sources. Cattle manure tended to increase the $\mathrm{P}$ and $\mathrm{K}$ contents of stargrass, whereas the contents of $\mathrm{Ca}$ and $\mathrm{Mg}$ remained unchanged.

Analyses of soil samples from individual plots after each 360-day period indicated that available $\mathrm{P}$ and exchangeable $\mathrm{K}$ tended to increase somewhat with manure applications as compared with T8 (table 6).

It can be concluded that sun-cured cattle manure can supply around $35 \%$ of the $\mathrm{N}$ and $10 \%$ of the $\mathrm{K}$ required for maximum dry forage production. Cattle manure at the highest rate of $31,360 \mathrm{~kg} / \mathrm{ha} /$ year (T7) increased DF yields significantly (by 61\%) over T8 without burning the grass (table 4). Lower amounts of cattle manure, 2,800, 5,600, 11,200,

TABLE 6.-Soil pH, phosphorus and potassium changes in an Ultisol after receiving different manure rates

\begin{tabular}{|c|c|c|c|c|c|c|c|c|c|}
\hline \multirow{2}{*}{ Treatment } & \multicolumn{3}{|c|}{$\begin{array}{l}\text { Original soil reaction and } \\
\text { concentration }\end{array}$} & \multicolumn{3}{|c|}{ After first year $1981^{1}$} & \multicolumn{3}{|c|}{ After second year $1982^{1}$} \\
\hline & $\mathrm{pH}$ & Phosphorus & Potassium & $\mathrm{pH}$ & Phosphorus & Potassium & $\mathrm{pH}$ & Phosphorus & Potassium \\
\hline 1 & 4.92 & 0 & 153 & 5.01 & 3.0 & 66 & 5.08 & 1.5 & 58 \\
\hline 2 & 5.15 & 0 & 170 & 5.64 & 3.5 & 60 & 5.53 & 3.0 & 77 \\
\hline 3 & 4.91 & 0 & 156 & 5.30 & 2.8 & 72 & 5.19 & 2.0 & 76 \\
\hline 4 & 5.26 & 0 & 206 & 5.69 & 4.0 & 74 & 5.25 & 1.8 & 82 \\
\hline 5 & 5.28 & 0 & 150 & 5.86 & 5.0 & 77 & 5.70 & 5.0 & 78 \\
\hline 6 & 5.07 & 0 & 165 & 6.15 & 3.0 & 121 & 5.79 & 7.8 & 91 \\
\hline 7 & 5.41 & 0 & 180 & 6.40 & 6.5 & 131 & 6.47 & 7.3 & 147 \\
\hline 8 & 5.00 & 0 & 122 & 5.52 & 1.5 & 40 & 5.46 & 2.8 & 50 \\
\hline
\end{tabular}

${ }^{1}$ Mean of 4 replicates at $0-15 \mathrm{~cm}$ soil depth.

16,800 , and $22,400 \mathrm{~kg} / \mathrm{ha} /$ year, supplemented with commercial fertilizer to provide 504, 73 and $336 \mathrm{~kg} / \mathrm{ha} /$ year of $\mathrm{N}, \mathrm{P}$, and $\mathrm{K}$, respectively, gave similar DF yields as T1 during the 720-day period (table 4). However, the extra costs of fertilizer must be compared to extra costs in terms of hand labor for hauling and applying huge amounts of manure.

\section{RESUMEN}

En 1981 y 1982 se realizó un experimento en la Subestación de Corozal para determinar los efectos del estiércol de vaca en los rendimientos de forraje verde, forraje seco y proteína bruta de la yerba estrella (Cynodon nlemfuensis var. nlenfuensis) y en la composición del suelo. El estiércol contenía $65 \%, 1.6 \%, .10 \%$ y $.34 \%$ de materia seca, nitrógeno, fósforo y potasio, respectivamente. Se aplicó a la yerba estrella en cantidades de $2,800,5,600,11,200,16,800,22,400$ y $31,360 \mathrm{~kg} / \mathrm{ha}$ y año y se segó cada 45 días. Los tratamientos se suplementaron con abono comercial $\mathrm{N}$ - 
P-K, hasta alcanzar 504, 73 y $336 \mathrm{~kg} / \mathrm{ha}$ y año de nitrógeno, fósforo y potasio, respectivamente. Se incluyeron además 2 tratamientos testigo, uno con 3,360 kg/ha y año de un abono 15-5-10, como abono corriente y otro sin abono y sin estiércol.

En los 720 días del estudio, la cantidad máxima de estiércol, sin abonamiento nitrogenado suplementario aumentó significativamente los rendimientos de forraje seco y proteína bruta sobre el testigo sin abonar. Los tratamientos de estiércol de 2,800 a 22,400 kg/ha y año produjeron rendimientos de forraje seco similares al tratamiento corriente. El estiércol aumentó los contenidos en fósforo y potasio, pero no en calcio y magnesio. También aumentó el fósforo disponible y el potasio cambiable del suelo al compararlos con el tratamiento sin abono.

Sin embargo, en futuros estudios a nivel de la finca, es necesario comparar los costos extraordinarios que se incurren en términos de labores necesarias para acarrear y aplicar grandes cantidades de estiércol en comparación con aplicar un abono comercial.

\section{LITERATURE CITED}

1. Arteaga, O., R. Chongo and A. Mojena, 1981. Utilización del estiércol vacuno como fuente de fósforo para los pastos, ALPA Mem. 16: 95 (Abs.).

2. Jones, P. A. and J. B. D. Robinson, 1965. Response of mature Napiergrass to fertilizers and cattle manure in Kenya, East Afr. Agric. For. J. 30 (3): 276-85.

3. Riera, A., 1955. The method of foliar diagnosis as applied to sugarcane, II. The chemical analyses of sugarcane-leaf samples, Univ. P. R. Agric. Exp. Stn. Bull. 123.

4. Sears, P. D., J. Melville and L. T. Evans, 1953. Pasture growth and soil fertility, N. Z. J. Sci. Technol, 35 Sect. A., Suppl. 1.

5. Semple, A. T., 1970. Grassland. Improvement, 1st. ed., C.R.C. Press, Cleveland, Ohio.

6. Snedecor, G. W. and W. G. Cochran, 1967. Statistical methods, 6th ed, The Iowa State Univ. Press, Ames, Iowa.

7. Sutton, A. L., D. W. Nelson, N. J. Moeller, and D. L. Hill, 1981. Application of cattle waste on sloping cropland. J. Dairy Sci. 64: 1742-8.

8. Vélez-Santiago, J., A. Sotomayor-Rios, and S. Torres-Rivera, 1979. Effect of three harvest intervals and two fertilizer rates on the yield and $\mathrm{HCN}$ content of ten Cynodon cultivars, J. Agric. Univ. P. R. 63 (1): 35-44. 